\title{
Influence of Close-Up Starting Programs on Performance of Light-Weight Feedlot Steers Calves during the Early Receiving Period
}

\author{
Rubén Barajas ${ }^{1}$, Jaime Salinas-Chavira², Richard A. Zinn ${ }^{3 *}$ \\ ${ }^{1}$ Facultad de Medicina Veterinaria y Zootecnia, Universidad Autónoma de Sinaloa, Culiacán, México \\ ${ }^{2}$ Facultad de Medicina Veterinaria y Zootecnia, Universidad Autónoma de Tamaulipas, Cd. Victoria, México \\ ${ }^{3}$ Animal Science Department, University of California, El Centro, USA \\ Email: razinn@ucdavis.edu
}

Received 8 July 2014; revised 24 August 2014; accepted 7 September 2014

Copyright (C) 2014 by authors and Scientific Research Publishing Inc.

This work is licensed under the Creative Commons Attribution International License (CC BY).

http://creativecommons.org/licenses/by/4.0/

c) (i) Open Access

\section{Abstract}

The influence of close-up feed strategies on growth performance and dietary NE in light-weight feedlot steers during a $56 \mathrm{~d}$ receiving period was evaluated. Dietary treatments were formulated to meet the average metabolizable amino acid requirements of calves during 1 ) the initial $7 \mathrm{~d} ; 2$ ) the initial $14 \mathrm{~d}$; and 3) the initial $21 \mathrm{~d}$ following arrival into the feedlot, assuming average interval DMI of 2.8, 3.0, and $3.6 \mathrm{~kg} / \mathrm{d}$, respectively. Thereafter, all steers received dietary treatment 3 . Fish meal was the source of supplemental protein. One hundred eight medium-framed crossbred steers $(168.4 \pm 5.0 \mathrm{~kg})$ were blocked by weight and assigned to 18 pen groups (6 steers per pen). $P$-value $(\leq 0.10)$ was considered as statistically significant. Daily weight gain (linear effect, $P=0.09$ ) and gain efficiency (linear effect, $P=\mathbf{0 . 0 8}$ ) decreased as the close-up interval increased. DMI was not influenced by feeding program $(P=0.46)$. The ratio of observed to expected dietary NEm (linear effect $P=0.06$ ) and $N E g$ (linear effect, $P=0.05$ ) decreased as length of close-up interval increased. Morbidity was low $(18 \%)$ and not affected $(P>0.40)$ by dietary treatments. It is concluded that the addition of a close-up diet formulated to meet the metabolizable amino acid requirements of shipping stressed calves during the initial $7 \mathrm{~d}$ in the feedlot, when feed intakes are comparatively low, will have long-term beneficial effect on cattle growth performance and dietary NE.

\section{Keywords}

Amino acid, Cattle, Receiving Period, Diets

\footnotetext{
${ }^{*}$ Corresponding author.
}

How to cite this paper: Barajas, R., Salinas-Chavira, J. and Zinn, R.A. (2014) Influence of Close-Up Starting Programs on Performance of Light-Weight Feedlot Steers Calves during the Early Receiving Period. Open Journal of Animal Sciences, 4, 217-221. http://dx.doi.org/10.4236/ojas.2014.45027 


\section{Introduction}

Receiving diets are typically formulated to meet the average protein requirements of calves during the course of the receiving period; however, feed intake during the first few weeks, when cattle are adapting to the feedlot environment, is characteristically low [1] [2]. Consequently, during this period protein nutrition may be grossly inadequate [3]-[5]. Fluharty and Loerch [6] found that during the initial $28 \mathrm{~d}$ receiving period newly arrived feedlot calves $(226 \mathrm{~kg}$ ) fed a 16\% CP diet had greater gain efficiency, than those fed a 12.5\% CP diet. However, treatment effects on weight gain were only evident during first week, when DMI was low. The potential for protein deposition is a function of both energy intake and metabolizable protein supply [7]. Most of the previous work evaluating protein nutrition during the receiving period has involved heavier weight calves or light yearlings [8]. The objective of the present study is to examine the influence of close-up feed strategies, matching metabolizable protein supply to expected DMI during the initial 7, 14, or $21 \mathrm{~d}$ of the receiving period, on $56 \mathrm{~d}$ growth performance and dietary NE in light-weight feedlot steers.

\section{Materials and Methods}

One hundred eight medium-framed crossbred steers $(168.4 \pm 5.0 \mathrm{~kg})$ originating from the Fortworth, Texas market area were trucked to the University of California, Desert Research and Extension Center. Upon arrival, calves were branded, castrated (elastration), vaccinated for IBR-PI3 (TSV-2, Zoetis, Inc., New York, NY), Clostridials/Haemophilus (Ultrabac 7, Zoetis, Inc., New York, NY), treated for internal and external parasites (Ivomec Plus, Merck, Rahway, NJ), injected with 500,000 units vitamin A (Vita-jec A\&D 500, RXV Products, Porterville, CA), and implanted with Synovex-C (Zoetis, Inc., New York, NY). Calves were blocked by arrival weight and assigned at random within weight groupings to 18 pens (6 steers per pen). Pens were $43 \mathrm{~m}^{2}$ with 22 $\mathrm{m}^{2}$ overhead shade, automatic waterers, and $2.4 \mathrm{~m}$ fence line feed bunks. Dietary treatments (Table 1) were formulatedto meet the average metabolizable amino acid requirements of calves [9] during: 1) the initial $7 \mathrm{~d}$; 2) the initial $14 \mathrm{~d}$; and 3) the initial $21 \mathrm{~d}$ following their arrival into the feedlot, assuming average interval DMI of $2.8,3.0$, and $3.6 \mathrm{~kg} / \mathrm{d}$, which correspond to $1.66 \%, 1.78 \%$ and $2.14 \%$ of BW, respectively. The DMI was estimated according to NRC [9]. After receiving respective close-up treatments, cattle were switched to dietary treatment 3 for the remainder of the $56 \mathrm{~d}$ feeding period. Calves had ad libitum access to feed. Fresh feed was added twice daily. The initial weight was the off-truck arrival weight. In the calculation of steer performance final live weights were reduce $4 \%$ to adjust for digestive tract fill. Estimates of steer performance were based on pen means. Net energy values for each diet were calculated from estimates of energy gain (EG, Mcal/d) based on growth-performance; $\mathrm{EG}=0.0557 \mathrm{BW}^{0.75}\left(\mathrm{ADG}^{1.097}\right)$, where $\mathrm{EG}$ is the daily energy deposited $(\mathrm{Mcal} / \mathrm{d})$, $\mathrm{BW}$ is the mean shrunk body weight (full weight $\times 0.96)$ and maintenance energy expended $(E M, M c a l / d)$; $E M=$ $0.077 \mathrm{BW}^{0.75}$ [10]. Dietary NEg was derived from NEm by the equation: NEg $=0.877 \mathrm{NEm}-0.41$ [11]. Dry matter intake is related to energy requirements and dietary NEm according to the equation: $\mathrm{DMI}=\mathrm{EG} /(0.877$ $\mathrm{NEm}-0.41)$, and can be resolved for estimation of dietary NE by means of the quadratic formula: $\mathrm{x}=(-\mathrm{b} \pm(\mathrm{b} 2-$ $\left.4 \mathrm{ac})^{0.5}\right) / 2 \mathrm{c}$, where $\mathrm{x}=\mathrm{NEm}, \mathrm{a}=-0.877 \mathrm{DMI}, \mathrm{b}=0.877 \mathrm{EM}+0.41 \mathrm{DMI}+\mathrm{EG}$, and $\mathrm{c}=-0.41 \mathrm{EM}$ [11].

Treatment effects were tested by means of orthogonal polynomials. Performance (gain, gain efficiency, and dietary energetics) data were analyzed as a randomized complete block design; the experimental unit was the pen. The MIXED procedure of SAS (SAS Inst. Inc., Cary, NC) was used to analyze the variables. Treatments effects were tested using the following contrasts: 1) linear effect of the days of program, and 2) quadratic effect of the days of program. P-value $(\leq 0.10)$ was considered as statistically significant. Effects of treatment were determined according to SAS (SAS Inst., Inc., Cary, NC; Version 9.1).

\section{Results and Discussion}

Treatment effects on growth performance responses of steers are shown in Table 2. Morbidity was low (18\%) and not affected $(\mathrm{P}>0.40)$ by dietary treatments. There were no treatment effects $(\mathrm{P}>0.10)$ on DMI. Mean DMI was $4.2 \mathrm{~kg} /$ day, $16 \%$ lower than otherwise expected (4.96 kg/day) for calves of that BW and NE content of the diets [9]. This lower level of intake reflects, in part, the adaptation of calves to eating complete mixed diets from a feedbunk during the receiving period [1] [5] [6].

Average daily gain (linear effect, $\mathrm{P}=0.09$ ) and gain efficiency (linear effect, $\mathrm{P}=0.08$ ) decreased as the length of the close-up interval increased. Improved ADG and gain efficiency observed in present study are consistent 
Table 1. Ingredients composition of experimental diets fed to steer (\% DM basis).

\begin{tabular}{|c|c|c|c|}
\hline \multirow[b]{2}{*}{ Items } & \multicolumn{3}{|c|}{ Close-up treatment diet } \\
\hline & $1-7 d$ & $1-14 d$ & $1-21 d^{a}$ \\
\hline Alfalfa hay & 15.00 & 15.00 & 15.00 \\
\hline Sudan grass, hay & 15.00 & 15.00 & 15.00 \\
\hline Corn, steam flaked & 51.30 & 53.30 & 54.30 \\
\hline Yellow grease & 2.00 & 2.00 & 2.00 \\
\hline Molasses cane & 8.00 & 8.00 & 8.00 \\
\hline Urea & 0.10 & 0.10 & 0.10 \\
\hline Fishmeal & 7.70 & 5.70 & 4.70 \\
\hline Limestone & 0.20 & 0.20 & 0.20 \\
\hline Magnesium, oxide & 0.20 & 0.20 & 0.20 \\
\hline Trace mineralized salt ${ }^{\mathrm{b}}$ & 0.50 & 0.50 & 0.50 \\
\hline \multicolumn{4}{|l|}{ Nutrient composition (DM basis) ${ }^{\mathrm{c}}$} \\
\hline $\mathrm{DE}, \mathrm{Mcal} / \mathrm{kg}$ & 4.07 & 4.10 & 4.11 \\
\hline ME, Mcal/kg & 2.92 & 2.94 & 2.94 \\
\hline \multicolumn{4}{|l|}{ NE, Mcal $/ \mathrm{kg}$} \\
\hline Maintenance & 1.98 & 2.00 & 2.00 \\
\hline Gain & 1.33 & 1.35 & 1.35 \\
\hline Crude protein, \% & 15.80 & 14.63 & 14.05 \\
\hline UIP, \% of CP & 42.63 & 41.21 & 40.40 \\
\hline DIP, \% of CP & 57.37 & 58.79 & 59.60 \\
\hline Calcium, \% & 0.89 & 0.78 & 0.73 \\
\hline Phosphorus, \% & 0.49 & 0.43 & 0.40 \\
\hline
\end{tabular}

${ }^{\mathrm{a}}$ Diet for remainder of the $56 \mathrm{~d}$. ${ }^{\mathrm{b}}$ Trace mineral salt contained: $\mathrm{CuSO}_{4} .068 \%$; $\mathrm{CuSO}_{4}, 1.04 \%$; $\mathrm{FeSO}_{4}, 3.57 \% ; \mathrm{ZnO}, 1.24 \%$; $\mathrm{MnSO}$, 1.07; $\mathrm{KI}, 0.52 \%$; and $\mathrm{NaCl}, 92.96 \%$. ${ }^{\mathrm{C}}$ Based on tabular values for individual feed ingredients (NRC, 1984 [10]) with the exception of supplemental fat, which was assigned NEm and NEg values of 6.03 and 4.79, respectively (NRC, 1996 [9]).

responses to improved protein nutrition of newly arrived feedlot calves [5] [6] [11]-[13]. Fluharty and Loerch [5] observed improved ADG and gain efficiency of newly received calves (238 kg) following a step-up program using diets with 23\% CP during wk 1, 17\% CP during wk 2, and 12.5\% CP during wks 3 and 4 . Zinn and Owens [14], conducted an 84 days experiment with growing steers (initial weight $198 \mathrm{~kg}$ ) fed a $12.2 \%$ CP basal diet supplemented with $2 \%, 4 \%$ and $6 \%$ of a rumen escape protein blend (blood meal, feather meal, meat and bone meal), the CP of those diets were $13.4 \%, 14.6 \%$ and $15.8 \%$ respectively. They observed that during first 28 days, ADG increased linearly with increased UIP protein intake.

In previous studies exploring the influence of protein supplementation in newly arrived cattle, cattle did not receive growth implants [5]-[7] [12] [20]. However, in the present study, steers received growth implants, as is the common practice in the industry [8]. Hormonal implants enhance amino acid uptake by muscle cells [15], increasing the number of satellite cells, rate of cell proliferation, and protein synthesis, and decreasing rate of protein degradation [16]. The net effect is a potential for increased $\mathrm{N}$ retention, provided cattle receive adequate metabolizable protein [17]-[20]. When diet formulations do not provide adequate metabolizable protein the partial efficiency of energy utilization for maintenance and gain is proportionally depressed. Accordingly, in the present study the observed/expected ratio of dietary NEm (linear effect, $\mathrm{P}=0.06$ ) and NEg (linear effect, $\mathrm{P}=$ 
Table 2. Treatment effect on 56 d growth performance of steers.

\begin{tabular}{|c|c|c|c|c|c|c|}
\hline \multirow[b]{2}{*}{ Item } & \multicolumn{3}{|c|}{ Close-up treatments diets } & \multicolumn{2}{|c|}{$\mathrm{P}$ values } & \multirow[b]{2}{*}{ SEM } \\
\hline & $1-7 d$ & $1-14 d$ & $1-21 d$ & Linear & Quadratic & \\
\hline Days on test & 56 & 56 & 56 & & & \\
\hline Pens & 6 & 6 & 6 & & & \\
\hline \multicolumn{7}{|l|}{ Live weight, $\mathrm{kg}^{\mathrm{a}}$} \\
\hline Initial & 168.4 & 170.1 & 166.8 & 0.58 & 0.34 & 2.024 \\
\hline $56 \mathrm{~d}$ & 228.6 & 227.1 & 220.8 & 0.09 & 0.53 & 3.026 \\
\hline DMI & 4.21 & 4.19 & 4.08 & 0.46 & 0.75 & 0.118 \\
\hline ADG & 1.07 & 1.02 & 0.96 & 0.09 & 0.98 & 0.043 \\
\hline ADG/DMI & 0.257 & 0.242 & 0.236 & 0.08 & 0.68 & 0.008 \\
\hline \multicolumn{7}{|l|}{ Dietary NE, Mcal $/ \mathrm{kg}$} \\
\hline Maintenance & 2.09 & 2.03 & 2.00 & 0.11 & 0.82 & 0.040 \\
\hline Gain & 1.43 & 1.37 & 1.34 & 0.11 & 0.82 & 0.035 \\
\hline \multicolumn{7}{|c|}{ Dietary NE, observed/expected } \\
\hline Maintenance & 1.06 & 1.02 & 1.00 & 0.06 & 0.66 & 0.020 \\
\hline Gain & 1.07 & 1.02 & 0.99 & 0.05 & 0.64 & 0.026 \\
\hline Sick days & 1.75 & 2.17 & 2.08 & 0.66 & 0.70 & 0.522 \\
\hline Morbidity, \% & 16.67 & 16.67 & 22.22 & 0.48 & 0.68 & 5.422 \\
\hline
\end{tabular}

${ }^{a}$ Initial weight is the off-truck arrival weight. Final BW was reduced $4 \%$ to account for fill.

0.05) decreased as length of the close-up interval increased. Likewise, Schroeder et al. [7] observed that when energy intake increases in absence of adequate metabolizable amino acid supply, $\mathrm{N}$ retention of beef steers is not enhanced, and consequently, gain efficiency is depressed.

\section{Conclusion}

It is concluded that addition of a close-up diet formulated to meet the metabolizable amino acid requirements of shipping stressed calves during the initial $7 \mathrm{~d}$ in the feedlot, when feed intakes are normally comparatively low, will have long-term beneficial effect on cattle growth performance.

\section{References}

[1] Hutcheson, D.P. and Cole, N.A. (1986) Management of Transit-Stress Syndrome in Cattle: Nutritional and Environmental Effects. Journal of Animal Science, 62, 555-560.

[2] Loerch, S.C. and Fluharty, F.L. (1999) Physiological Changes and Digestive Capabilities of Newly Received Feedlot Cattle. Journal of Animal Science, 77, 1113-1119.

[3] Cole, N.A., Defoor, P.J., Galyean, M.L., Duff, G.C. and Gleghorn, J.T. (2006) Effects of Phase-Feeding of Crude Protein on Performance, Carcass Characteristics, Serum Urea Nitrogen Concentrations, and Manure Nitrogen of Finishing Beef Steers. Journal of Animal Science, 84, 3421-3432. http://dx.doi.org/10.2527/jas.2006-150

[4] Duff, G.C. and Galyean, M.L. (2007) Recent Advances in Management of Highly Stressed, Newly Received Feedlot Cattle. Journal of Animal Science, 85, 823-840. http://dx.doi.org/10.2527/jas.2006-501

[5] Fluharty, F.L. and Loerch, S.C. (1995) Effects of Protein Concentration and Protein Source on Performance of Newly Arrived Feedlot Steers. Journal of Animal Science, 73, 1585-1594.

[6] Fluharty, F.L. and Loerch, S.C. (1996) Effects of Dietary Energy Source and Level on Performance of Newly Arrived Feedlot Calves. Journal of Animal Science, 74, 504-513. 
[7] Schroeder, G.F., Titgemeyer, E.C. and Moore, E.S. (2007) Effects of Energy Supply on Leucine Utilization by Growing Steers at Two Body Weights. Journal of Animal Science, 85, 3348-3354. http://dx.doi.org/10.2527/jas.2006-789

[8] Galyean, M.L. (1996) Protein Levels in Beef Cattle Finishing Diets: Industry Application, University Research, and Systems Results. Journal of Animal Science, 74, 2860-2870.

[9] NRC (1996) Nutrient Requirements of Beef Cattle. 7th Edition, National Academy Press, Washington DC.

[10] NRC (1984) Nutrient Requirement of Beef Cattle. 6th Edition, National Academy of Sciences, Washington DC.

[11] Zinn, R.A. and Shen, Y. (1998) An Evaluation of Ruminally Degradable Intake Protein and Metabolizable Amino Acid Requirements of Feedlot Calves. Journal of Animal Science, 76, 1280-1289.

[12] Cole, N.A. and Hutcheson, D.P. (1990) Influence of Dietary Protein Concentrations on Performance and Nitrogen Repletion in Stresses Calves. Journal of Animal Science, 68, 3488-3497.

[13] Fluharty, F.L. and Loerch, S.C. (1994) Effects of Energy Density and Protein Source on Diet Digestibility and Performance of Calves after Arrival at the Feedlot. Journal of Animal Science, 72, 1616-1622.

[14] Zinn, R.A. and Owens, F.N. (1993) Ruminal Escape Protein for Lightweight Feedlot Calves. Journal of Animal Science, 71, 1677-1687.

[15] Kerth, C.R., Montgomery, J.L., Morrow, K.J., Galyean, M.L. and Miller, M.F. (2003) Protein Turnover and Sensory Traits of Longissimus Muscle from Implanted and Nonimplanted Heifers. Journal of Animal Science, 81, 1728-1735.

[16] Dayton, W.R. and White, M.E. (2014) Meat Science and Muscle Biology Symposium—Role of Satellite Cells in Anabolic Steroid-Induced Muscle Growth in Feedlot Steers. Journal of Animal Science, 92, 30-38. http://dx.doi.org/10.2527/jas.2013-7077

[17] Titgemeyer, E.C., Spivey, K.S., Parr, S.L., Brake, D.W. and Jones, M.L. (2012) Relationship of Whole Body Nitrogen Utilization to Urea Kinetics in Growing Steers. Journal of Animal Science, 90, 3515-3529. http://dx.doi.org/10.2527/jas.2011-4621

[18] Cacava, M.J. and Hancock, D.L. (1994) Effects of Anabolic Steroids on Nitrogen Metabolism and Growth of Steers Fed Corn Silage and Corn-Based Diet Supplemented with Urea or Combination of Soybean Meal and Feather Meal. Journal of Animal Science, 72, 515-522.

[19] Awawdeh, M.S., Titgemeyer, E.C., Schoreder, G.F. and Gand, D.P. (2006) Excess Amino Acid Supply Improves Methionine and Leucine Utilization by Growing Steers. Journal of Animal Science, 84, 1801-1810. http://dx.doi.org/10.2527/jas.2005-557

[20] Davenport, G.M., Boling, J.A. and Gay, N. (1990) Performance and Plasma Amino Acids of Growing Calves Fed Corn Silage Supplemented with Ground Soybeans, Fishmeal and Rumen-Protected Lysine. Journal of Animal Science, 68, 3773-3779. 
Scientific Research Publishing (SCIRP) is one of the largest Open Access journal publishers. It is currently publishing more than 200 open access, online, peer-reviewed journals covering a wide range of academic disciplines. SCIRP serves the worldwide academic communities and contributes to the progress and application of science with its publication.

Other selected journals from SCIRP are listed as below. Submit your manuscript to us via either submit@scirp.org or Online Submission Portal.
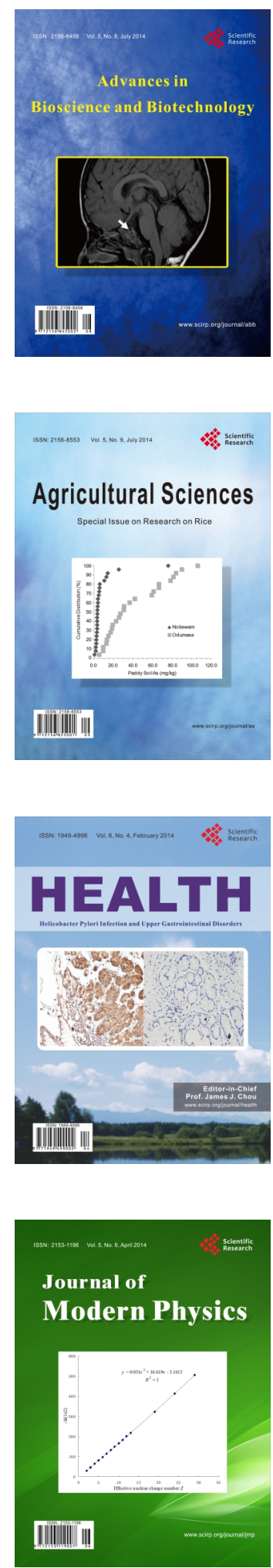
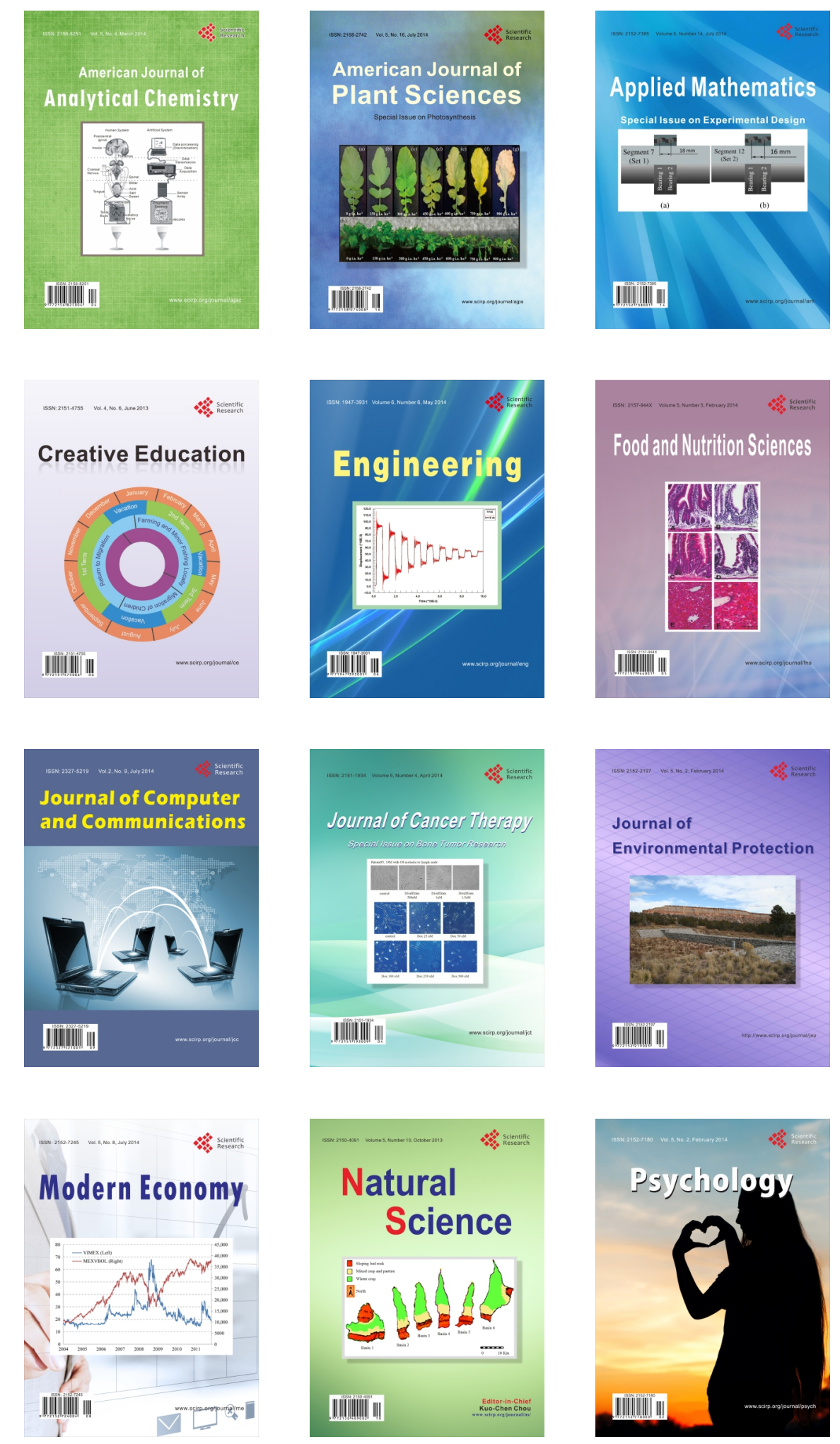